\title{
THE IMPACT OF TOTAL QUALITY MANAGEMENT ON SERVICE QUALITY, CUSTOMER ENGAGEMENT, AND CUSTOMER LOYALTY IN BANKING
}

\author{
Rosa Harimurti ${ }^{1}$, Tatik Suryani ${ }^{2 *}$ \\ ${ }^{1}$ Department of Business and Marketing Management STIE Perbanas, Jl. Nginden Semolo No.34-36, \\ Surabaya 60118, Indonesia \\ ${ }^{2}$ Master of Management STIE Perbanas, Jl. Nginden Semolo No.34-36, Surabaya 60118, Indonesia \\ Email: ${ }^{1}$ harimurtir@gmail.com; ${ }^{2}$ tatik@perbanas.ac.id \\ *Corresponding author
}

\begin{abstract}
The purpose of the research is to examine the impact of Total Quality Management (TQM) implementation on Service Quality, the effect of Service Quality on Customer Engagement and Customer Loyalty in banking industry. The other objective of the research also to examine the effect of Customer Engagement on Customer Loyalty. This research was conducted in East Java Province which involved 209 State Owned Enterprises (SOE) bank customer's as respondents. All variables are measured by Likert scale from bank customer perspectives. By Partial Least Square SEM analysis, the research found that TQM practices has positive effect on Service Quality, Service Quality has positive effect on Customer Engagement and Customer Loyalty and Customer engagement has positive effect on Customer Loyalty. The implication of this research is that SOE banks should implement TQM well so that it has a positive impact on service quality.
\end{abstract}

Keywords: Total quality management, service quality, customer engagement, customer loyalty.

\section{Introduction}

The biggest challenge for global business is to survive and achieve better business performance in the global market (Zakuan, Yusof, Laosirihongthong, $\&$ Shaharoun, 2010). Quality management has an important role for improving business performance. Total Quality Management (TQM) practices will affect the company's business performance (Psomas $\&$ Jaca, 2016). Other research also found the positive outcome of TQM implementation in banking (Petnji, Marimon, \& Casadesus, 2011).

State Owned Enterprise (SOE) banks as a global business also faced many challenges to achieve better performance. SOE banks in Indonesia have to compete with foreign banks. SOE banks such as Mandiri, BTN, BNI, and BRI should operate more efficiently than foreign banks and provide world-class services in order to win the competition. In fact, they are not as efficient as Thailand and Philippines Banks (Mongid \& Muazaroh, 2017). In addition, the service quality should be improved. Hence, in order to improve their efficiency, it is important for SOE to improve their TQM, their service quality and other business performance. This competition is predicted to be even higher in 2020 where the Asean financial sector integration will be carried out.

TQM research is essential because it could discover critical factor to support TQM implementation, especially within the service sector which are rarely studied (Al-Tabbaa, Gadd, \& Ankrah, 2013; Mensah, Copuroglu, \& Fening, 2012). In detail, TQM research is rarely done within banking service and its impact toward marketing performance such as customer engagement and customer loyalty.

TQM consists of five important dimensions such as such as customer focus, management involvement, continuous improvement, organizational context definition, and continuous improvement (Psomas \& Jaca, 2016). In practice, to improve the banking service TQM, company should consider these dimension.

This research is specifically focused in the effect of TQM toward marketing performance which are service quality (Psomas \& Jaca, 2016). This is important because customer engagement could affect customer engagement and loyalty (Hapsari, Clemes, \& Dean, 2017).

\section{Total Quality Management (TQM)}

Total Quality Management (TQM) is a way to continuously improve performance at each level of the process, in each functional area of an organization, by using all available human and capital resources. By implementing TQM, bank enable identifies customer requirements, improve process to deliver services, and reduce error in services (Baidoun, Salem, \& Omran, 2018). 
The aim of TQM is to improve service quality in the hope of fulfilling and satisfying the needs and desires of the target customers. Previously studies reported the benefits of TQM implementation such as increasing the efficiency and productivity, market share, employees' morale, quality, employee performance and competitive advantage (Sadikoglu \& Zehir, 2010; Zairi, 2013; Weckenmann, Akkasoglu, \& Werner, 2015; Rad, 2005).

The aim of TQM is to improve service quality in the hope of fulfilling and satisfying the needs and desires of the target customers. Psomas and Jaca (2016), TQM components for the advancement of service quality include: total employee involvement, continuous improvement, ongoing training, teamwork, empowerment, commitment and support from top management, democratic management style, customer satisfaction focus and quality culture. After reviewing the description above, this study focuses on three dimensions of TQM are the quality of human resources, customer focus, and employee knowledge. Three of dimensions will be described in the following explanation:

\section{Human Resources (HR) Development Quality}

TQM implementation is highly influenced by top leaders' commitment toward human resource (HR) development. (Talib, Rahman, \& Qureshi, 2013). HR development result could be described as the ability of employees to provide internal and consumer services, such as speed of service and solutions to applicable customer complaints in government banks that apply to customers (Psomas \& Jaca, 2016). The company can develop HR through various programs which enable employees to fulfill their job specifications, including on the job training (OJT), skills training, and career development. Employee development is also influenced by the commitment of each employee to develop (Lau \& Tang, 2009). The quality of HR development is a measured based on the competency development program or HR training and employees' commitment to develop competencies (Psomas \& Jaca, 2016).

\section{Customer Focus}

In TQM, customer focus is an essential part of company to improve their service quality. Customers focus consists of internal and external customers who will determine the direction of the company's quality. Internal customers are the company or employees who are responsible for customers, whereas external parties are customers who determine the direction of the company's quality. The customer focus can be measured based on several indicators (Psomas \& Jaca, 2016). These indicators are ease of customer complaint, consumer evaluation, and consumer treatment.

\section{Employees Knowledges}

Employee knowledge is important toward customer service. Employee who has good or enough knowledge could explain and solve customer problem. This knowledge is practiced when the employee informs, handle complaints, and give other services to the customers (Psomas \& Jaca, 2016).

\section{Service Quality}

In banking industry, service quality has strategic role for gaining competitive advantage. It's difficult to differentiate product in banking industry, so service quality become one of the attribute to distinguish bank from another bank. According to Khorshidi, Naghash, and Mohammadian (2014) high quality of services enable bank achieving competitive advantage.

There are many definitions and concept about service quality. Most of previously studies revealed that satisfaction is the result of a process of comparison between customer's expectations and perceptions of performance (Shayestehfar \& Yazdani, 2019). When customers perceive about many kinds of service attributes, it means that they evaluate about quality of services.

Zeithaml et al. (1988) in Lin (2012), identifying SERVQUAL dimensions into five aspects as follows:

- Tangibility: Physical facilities, equipment, and personnel appearance.

- Reliability: Able to perform the promised service properly and accurately.

- Responsiveness: Willingness to help customers and provide prompt service.

- Assurance: Knowledge and politeness of employees, as well as their ability to convey trust and confidence.

- Emphaty: Caring, individual attention given by service providers to their customers.

SERVQUAL model is chosen to measure service quality because it could portrait service dimensions and it could be measured based on the banking service customer perspective (Fauzi \& Suryani, 2019).

An excellent service is a service that prioritizes customers with high quality who prioritize fast, reliable service, understand customer needs, in this case customer focus (Rahmayanti, 2010). If the implementation of service quality is implemented in an integrated manner, it will make customers feel valued. 


\section{TQM Implementation and Service Quality}

Based on the description above, the implementation of TQM on the company will improve the quality of service to customers (Calvo-Mora, Picón, Ruiz, \& Cauzo, 2014). TQM implementation could affect quality service improvement (Psomas \& Jaca, 2016). Company whose top management implement TQM will have higher commitment to develop their HR. Furthermore, they will also be more focused on their customer as well having higher concern toward employee knowledge. All these factors will affect the company service quality toward its customer. Hence, based on The first hypothesis in this study is:

$H_{l}$ : Implementation of the TQM Dimension has positive significantly effect on service quality in banking industry.

\section{Customer Engagement (CE)}

Customer engagement occurs on two parties who will be involved in a relationship with marketing are between consumers or companies. The occurrence of involvement between customers and companies is because there are dynamic relationships and emotional attachments in the transaction process. So et al. (2012) in Hapsari et al. (2017) identify five dimensions of customer engagement:

1. The level of a consumer's perception or sense of belonging to the brand (identification);

2. Levels of attention that focus and connect with the brand (attention);

3. Level of passion and interest in brand (enthusiasm);

4. Pleasant conditions where the customer animates with a positive response when playing the role of the customer brand (absorption);

5. Various levels of participation that customers have with brands (interaction).

Customer engagements play an important role in a company, where in making customer engagement or customer involvement as a company's marketing strategy, it will achieve the company's goals of increasing customer loyalty. Loyalty increases because there is a positive response from consumers to the company that raises interest in other consumers (So, King, Sparks, \& Wang, 2016). CE represents a person's psychological state, characterized by a certain level of intensity that plays a central role in the process of customer involvement. Apart from that it is an impact in the CE process. Thus, $\mathrm{CE}$ is defined as a multidimensional concept consisting of cognitive, emotional, and behavioral dimensions (Brodie et al., 2011 in Fernandes \& Esteves, 2016). According to
Hapsari et al. (2017), Dhasan, Suwanna, and Theingi (2017), customer engagement is measured based on two indicators: (1) a sense of pride in the company, (2) Feel comfortable with the company.

\section{Customer Loyalty}

Customer loyalty is a deeply held commitment to repurchase or rebuy preferred products or services consistently in the future. (Ribbink, van Riel, Liljander, \& Streukens, 2004). Loyal customer will most likely buy rather than a normal customer. Griffin (2002) stated that a consumer is said to be loyal or loyal if the consumer shows buying behavior regularly or there is a condition which requires consumers to buy at least twice in a certain time interval.

Kotler and Keller (2012) argue that, loyalty is a commitment held deeply to buy or support a product or service that is favored in the future even though the influence of the situation and marketing efforts has the potential to cause customers to switch. According to Hapsari et al. (2017), Dhasan et al. (2017), customer loyalty is measured from consumer behavior such as: their willingness to recommend to others, their preferences to the product and intensity to consume / buying products.

Customer loyalty is not only about attitude but also behavior (Suryani, 2013). So, in many research for measuring customer loyalty can be seen form attitude (affective, cognitive, and conative components) and behavior related with product or services.

\section{Service Quality on Customer Engagement (CE) and Customer Loyalty}

Maintaining the quality of service so that it remains good is very necessary for the company so that the customer's perception of the company is positive. The quality of service will have a positive impact on companies $\mathrm{CE}$ by involving the competencies of each internal company to customers. The decision is on the part of the customer that the quality received can meet their needs and desires. If the quality received by the customer is in line with expectations or even exceeds, the customer feels proud, happy, satisfied, and their expectations are realized.

The research results of Dhasan et al. (2017) which show that, from the functional side of service quality, it has a significant effect on customer engagement (CE) in the offline context. Consumers will respond positively to services that are accepted by recommending to others. Companies need to improve service quality to maintain and increase consumer loyalty. The positive response that consumers will give when the quality received can be felt to meet the 
needs of consumers is to be loyal to the selected product. Kotler and Keller (2012) also argue that loyalty is a commitment held deeply to buy or support a product or service that is favored in the future even though the influence of the situation and marketing efforts have the potential to cause customers to switch.

Lin (2012), which states that multi - channel service quality as measured by SERVQUAL dimensions has a significant effect on consumer loyalty. These dimensions are tangibility, responsiveness, and empathy. In accordance with the opinion of Zeithaml et al. (1988) in Lin (2012) Tangibility dimensions in the form of physical evidence, facilities, and personal appearance. The responsiveness dimension is willingness to help customers and provide fast service, and the empathy dimension is how service providers pay attention to individuals by providing solutions to customer complaints. In addition, the results of testing So et al. (2016), which states that service brand evaluation with indicators of service quality, perceived value, and customer satisfaction, has a significant effect on brand loyalty but not as much as other variables. Then the second and third hypotheses of this study are:

$\mathrm{H}_{2}$ : Service quality has a significant positive effect on customer loyalty in banking industry.

$H_{3}$ : Service quality has a significant positive effect on customer engagement in banking industry.

\section{Customer Engagement (CE) and Customer Loyalty}

The customer concept plays an important role in building customer loyalty to the brand. Interaction with companies, facilitate better business decisions and encourage customer loyalty. Dhasan et al. (2017) in their research explored the impact of customers online and their effect on customer brand loyalty. The role of online experience has a greater influence on the positive influence of customer loyalty on the brand.

In addition, customers are willing to share their experience and quality of service with their family and friends and also with service providers, (Theingi et al., 2016 in Dhasan et al., 2017). The company will strive to gain a competitive edge on the quality of service that given to customers, because customers with a positive mindset will have an impact on increasing positive WOM to relatives or other people. So et al. (2016), also states that customer engagement has a significant effect on brand loyalty. states that overall customer engagement factors have the greatest influence on loyalty when compared to other variables. So the fourth hypothesis of this study is:

$H_{4}$ : Customer engagement has a significant positive effect on customer loyalty in banking industry.

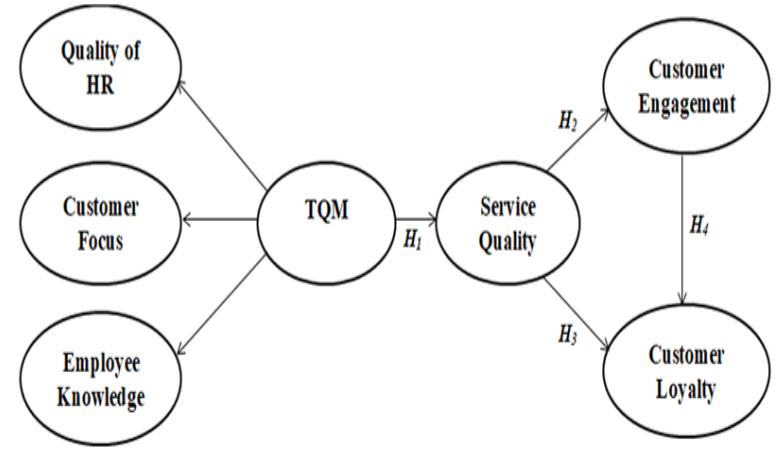

Figure 1. The conceptual research framework

\section{Research Methods}

This study use survey methodology using questioner as the instrument to gather data. Variables were measured by Likert scale with five categories of responses ranging from strongly disagree (score 1) to strongly agree (score 5) where respondents were asked to indicate the level of agreement or disagreement with some statements related to the object (Malhotra, 2010). Sample selected based on purposive sampling. They must be SOE bank customers in Surabaya and Sidoarjo, and Gresik.

There are two steps required to gather data, which are:

1. Finding Bank customer which meet certain criteria, such as: customer of SOE bank who are actively using the banking service at least one every two weeks and live in Surabaya or Sidoarjo or Gresik.

2. Customer fill the questioners, including their profile and the questions regarding this study.

Purposive sampling technique where the sample is selected according to several criteria (Sugiyono, 2015) is used in this study. The criteria used in this study are people who have signed up as the bank customer for at least two years, and within one month the customer must interact minimum of two times within the bank.

In total, 235 questionnaires were distributed to respondents who meet the sampling criteria. According to the previous research conducted by Ghozali and Latan (2014), the sampling size is sufficient to represent the population. However, from 235 questionnaires twenty-six questionnaires were not returned to the author. In the end there are $88.94 \%$ response rate within this study.

WarpPLS 4.0 is used to analyze the data in this study. WarpPLS 4.0 is one of many alternative method for structural equation models (SEM), which is to test simultaneously the relationship between latent constructs in linear or nonlinear relationships with many indicators in the form of A mode (reflective), B mode (formative) and or M mode 
(MIMIC) (Ghozali \& Latan, 2014). The steps of this research method include:

1. Model conceptualization

2. Determine the method of analysis algorithm

3. Determine the resampling method

4. Draw a path diagram

5. Evaluate the model

\section{Results and Discussion}

\section{Validity and Reliability Analysis}

The analysis of validity and reliability is presented in Table 1. The items are valid if the loading factor value is between $0.6-0.7$. Hence, all the items are valid (Ghozali \& Latan, 2014)

Table 1

Indicator Loadings and Latent Variable Coefficient

\begin{tabular}{lllcc}
\hline Item & $\begin{array}{c}\text { Factor } \\
\text { Loading }\end{array}$ & $\boldsymbol{P}$ Value & $\begin{array}{c}\text { Cronbach's } \\
\text { Alpha }\end{array}$ & $\begin{array}{c}\text { Composite } \\
\text { Reliability }\end{array}$ \\
\hline HR1 & 0.892 & $<0.001$ & 0.913 & 0.935 \\
HR2 & 0.867 & $<0.001$ & & \\
HR3 & 0.817 & $<0.001$ & & \\
HR4 & 0.874 & $<0.001$ & & \\
HR5 & 0.854 & $<0.001$ & & \\
CF1 & 0.8 & $<0.001$ & 0.886 & 0.913 \\
CF2 & 0.82 & $<0.001$ & & \\
CF3 & 0.751 & $<0.001$ & & \\
CF4 & 0.815 & $<0.001$ & & \\
CF5 & 0.841 & $<0.001$ & & \\
CF6 & 0.758 & $<0.001$ & & \\
EK1 & 0.78 & $<0.001$ & 0.868 & \\
EK2 & 0.833 & $<0.001$ & & \\
EK3 & 0.738 & $<0.001$ & & \\
EK4 & 0.861 & $<0.001$ & & \\
EK5 & 0.833 & $<0.001$ & & \\
SQ1 & 0.755 & $<0.001$ & 0.917 & \\
SQ2 & 0.741 & $<0.001$ & & \\
SQ3 & 0.762 & $<0.001$ & & \\
SQ4 & 0.78 & $<0.001$ & & \\
SQ5 & 0.788 & $<0.001$ & & \\
SQ6 & 0.825 & $<0.001$ & & \\
SQ7 & 0.827 & $<0.001$ & & \\
SQ8 & 0.818 & $<0.001$ & & \\
SQ9 & 0.685 & $<0.001$ & & \\
CE1 & 0.786 & $<0.001$ & 0.913 & \\
CE2 & 0.847 & $<0.001$ & & \\
CE3 & 0.814 & $<0.001$ & & \\
CE4 & 0.867 & $<0.001$ & & \\
CE5 & 0.85 & $<0.001$ & & \\
CE6 & 0.847 & $<0.001$ & & \\
CL1 & 0.874 & $<0.001$ & 0.924 & \\
CL2 & 0.783 & $<0.001$ & & \\
CL3 & 0.845 & $<0.001$ & & \\
CL4 & 0.801 & $<0.001$ & & \\
CL5 & 0.817 & $<0.001$ & & \\
CL6 & 0.849 & $<0.001$ & & \\
CL7 & 0.827 & $<0.001$ & & \\
& & & & \\
\end{tabular}

The reliability analysis in Table 2 show that the AVE root value of HR development (HR) is 0.74 . Customer Focus (CF) value is 0.64, Employee Knowledge (EK) value is 0.66 , and Service Quality (SQ) is 0.6 , Customer Engagement (CE) value is 0.7 and lastly Customer Loyalty (CL) value is 0.69 . According to these results, all the instrument used to measure the variable are all reliable. This is because the composite reliability value range between 0.6-0.7 (Abdillah \& Jogiyanto, 2015).

Table 2

Correlations Among Latent Variables and Errors

\begin{tabular}{ccccccc}
\hline & HR & CF & EK & SQ & CE & CL \\
\hline AVE & 0.74 & 0.64 & 0.66 & 0.60 & 0.70 & 0.69 \\
\hline
\end{tabular}

Descriptive analysis in Table 3 shows that all the variables which are TQM implementation, Service Quality, Customer engagement and Customer Loyalty have mean in high category. It means bank have implemented TQM in good conditions, they have high service quality. From SOE bank it's a good asset for gaining advantage in facing competition with private bank and financial institutions who deliver the same services.

Table 3

Descriptive Analysis of Variables

\begin{tabular}{lcc}
\hline \multicolumn{1}{c}{ Variables } & Mean & Category \\
\hline TQM Implementation & 3.99 & High \\
HR Development Quality (HR) & 4.05 & High \\
Customer Focus (CF) & 3.91 & High \\
Employee Knowledge (EK) & 4.02 & High \\
Service Quality & 4.01 & High \\
Customer Engagement & 3.73 & High \\
Customer Loyalty & 3.80 & High \\
\hline
\end{tabular}

\section{Results of PLS-SEM Analysis}

The result of data analysis conducted using WarpPLS 4.0 is shown in Figure 2. The results show that:

1. Human Resource Management development quality (HR), Customer Focus (CF), and Employee Knowledge (EK) are the dimensions of TQM implementation. HR development quality has positive effect significantly Service Quality ( $p$ value < 0.01 smaller than required, which is $<0.01)$. The direction of the relationship between HR quality and service quality is positive 0.274 . Then the relationship between customer focus (CF) and service quality (SQ) has also significant with $p$ value < 0.01 . The path coefficient value of 0.221 indicates that the direction of the relationship between 
customer focus and service quality is positive. The relationship between relationship between employee knowledge $(\mathrm{EK})$ with service quality is also significant with a value of $p$ value $<0.01$.

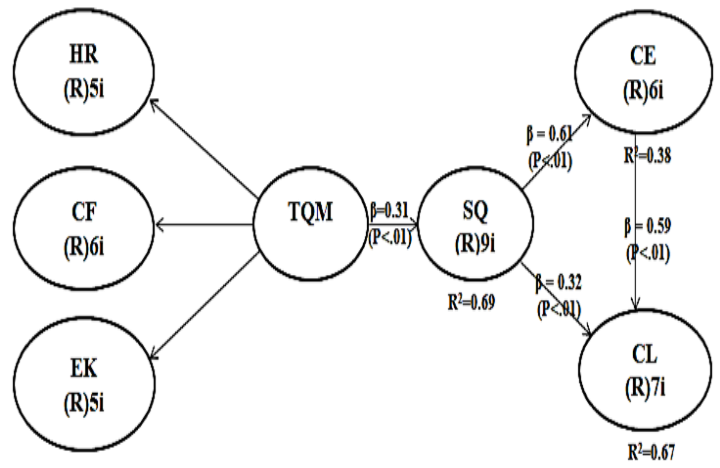

Figure 2. Outer model framework

Table 4

Path Coefficient

\begin{tabular}{lcccccc}
\hline & HR & CF & EK & SQ & CE & CL \\
\hline SQ & 0.274 & 0.221 & 0.436 & & & \\
CE & & & & 0.614 & & \\
CL & & & & 0.315 & 0.591 & \\
\hline
\end{tabular}

The path coefficient value of 0.436 means that the results show that the relationship between knowledge of employees (KE) and service quality (SQ) is positive.

2. TQM implementation has positive effect significantly on Service Quality (SQ) $(p<0.01)$ and the coefficient value 0.31 ).

3. Service quality has positive significantly effect on customer engagement ( $p$ value $<0.01$ ). The direction of the relationship between service quality and customer engagement is positive because the path coefficient value is 0.614 . So the $H_{2}$ hypothesis which states service quality (SQ) has a positive significant effect on Customer Engagement (CE) is accepted.

3. Service quality has positive effect significantly on customer loyalty ( $p$ value $<0.01$ ). The direction of the relationship between service quality and customer loyalty is positive with path coefficient value is 0.315 . So, $H_{3}$ hypothesis which states service quality (SQ) has a significant positive effect on Customer Loyalty (CL) is accepted.

4. Customer engagement has positive effect significantly on customer loyalty ( $p$ value $<0.01$ ). The direction of customer engagement and customer loyalty is positively with path coefficient value is 0.591 . It means that the $H_{4}$ hypothesis which states Customer Engagement (CE) has a significant positive effect on Customer Loyalty $(\mathrm{CL})$ is accepted.

\section{Discussion}

The purpose of this research is to examine the effect of the Implementation of Total Quality Management (TQM) from customer perceptions on Service Quality, Customer Engagement, and Customer Loyalty in government bank.

\section{Effect of the Implementation of TQM on Service Quality}

The result on this study show that the implementation of TQM could positively impact the service quality of SOE banks. This result is also consistent with the previous study conducted by Psomas and Jaca (2016). Previous studies and this study showed that the TQM implementation contributes to company performance, such as financial performance, product/ service quality, customer satisfaction, and operational performance (Psomas \& Jaca, 2016).

These results indicate that better the quality of human resource development, the better will it affect the company TQM implementation. Similarly, the better company employee knowledge will also affect the company TQM implementation.

Research in small service organization in Malaysia also found that implementation of TQM has positive significantly effect on satisfaction and service quality (Ooi, Lin, Tan. \& Chong, 2011). Service quality provided by the bank to its customer will also improve it is supported by better human resource quality and better human resource management.

Furthermore, other factor such as Customer Focus play important role in TQM implementtation (Psomas \& Jaca, 2016). Customer centric company view that ultimately the customer will judge the company quality. Company who actively listen and try to meet customer expectation will serve customer better.

In addition, customer centric company will involve customer in their product development. According to Flynn et al. (in Herzallahah, GutiérrezGutiérrez, \& Rosas, 2014), customer development in product or service development will reduce future potential risk problem within the production process. By involving customer, the production process will result in a product/service that meet the customer needs.

\section{Effect of Service Quality on Customer Engagement (CE)}

The result show that service quality has a significant positive effect toward customer engagement in SOE banks. This study is consistent with the previous 
study conducted by Dhasan et al. (2017) which showed that based from the the functional side of service quality, it has a significant effect on customer engagement (CE) in the offline context. The functional aspect within banking service quality consist of products knowledge, ability to serve faster, ability to help customer, willingness to overcome customer complaints, and employee hospitality and courtesy when serving the customer. If the banks give a quality service toward its customer, customer are most likely willing to engage with the bank. Furthermore, customer who had served with good quality service will also engage with other customers (Dhasan et al., 2017). This positive experience regarding the bank service will drive customer engagement on the company.

In this study, customers were giving good marks on bank who provide secure online transactions. This secure online transaction is shown by the availability of PIN code change which could protect the customers. In addition, this initiative is positively perceived by the customer. Therefore, customers are more willing to engage with SOE banks. Security as a part of service quality could determine the superiority of service quality offered by a company. In the end the good and bad service quality provided by the company could affect the customer engagement toward SOE banks.

\section{Effect of Service Quality on Customer Loyalty}

The results show that service quality has a significant positive effect on customer loyalty at government banks. The results of the study are the same as the results of previous research conducted by Lin (2012), which states that the multi-channel service quality supported by the SERVQUAL dimensions have a significant effect on consumer loyalty. Customer who perceived a good service quality will stay loyal as a customer for the bank. They are less willing to change their banks, which ultimately show their loyalty toward the bank.

This study result also in line with the previous study conducted by So et al. (2016), which proved that service quality has a significant effect on loyalty. There are three key element which contributes in service quality, those are employee responsiveness when serving its customer, the banking atmosphere which result in more comfortable customer. All of these will affect customer loyalty. Banks should view this as an important factor because if it's done correctly, the could save their promotion budget. Furthermore, loyal customer could also act as a good marketer for the bank products and service. When the customer is loyal toward a bank, customer will more likely to only use the service or product offered the banks rather than churning or using other banks (Kotler \& Keller, 2012).

\section{Effect of Customer Engagement (CE) on Customer Loyalty}

Based on the analysis, the results show that customer engagement has a significant positive effect on customer loyalty at government banks. This result was consistent with the previous studies conducted by Hapsari et al. (2017) which states that customer engagement has a significant positive effect on passenger loyalty. Customer who engage with the banks could be viewed as a loyal customer and will most likely stay with the same bank for a longer time or commitment,

The results of the study also support the previous study conducted by Dhasan et al. (2017) who found that customer engagement in an offline context has a significant effect on consumer loyalty. In this study, the determinant of offline is that people say positive things and recommend to others. In addition, the research conducted by So et al. (2016), also states that customer engagement has a significant effect on brand loyalty. This research also found that overall customer engagement factors had the greatest influence on loyalty when compared to other variables, such as satisfaction.

The more positive customer involvement in the company, the more it will increase customer loyalty to the SOE bank they choose. The positive engagement from customer toward the bank is shown as their intention to promote the superiority of the bank products/service to the other customers, telling a positive experience, and recommend the bank product/service to their friends or banks customers. Customer who engage with bank tend to show several behaviors such as identification, enthusiasm, and absorption which also included in the Customer Engagement variable (So et al., 2012 in Hapsari et al., 2017).

\section{Conclusion}

The result of this study shows that the implementation of TQM which focused on three dimensions of TQM including Human resource development quality, Customer Focus and Employee knowledge could positively affect toward SOE bank service quality. Better service quality will result in improvement toward Customer Engagement (CE) and SOE bank customer loyalty. In addition, Customer Engagement (CE) itself could positively affect SOE bank customer loyalty. 
The implication of this study show that within the implementation of TQM, SOE bank should actively seek to improve human resource development, customer focus, and improve employee knowledge. All of these three could contribute positively toward the improvement of SOE bank service quality. In order to improve employee knowledge, SOE bank should conduct training program, coaching, and knowledge sharing within the workplace. Thus, a great service quality will positively affect customer engagement and customer loyalty.

Secondly, the service quality SOE bank should focus is to improve employee respond on solving customer problem when they engage with their problem. In result this will improve positive customer experience from the customer.

Thirdly, SOE Banks should not neglect their technology quality to support their customer. The development of digital technology enables customer to access the banks without any constraint such as time and place. Technology allow customer to get faster information and it also improves customer ease of access toward the banks. These are also viewed as important in the perspective of customer.

There is also limitation of this study. The future study should review all the TQM dimensions. This will help company to discover the full implementation within TQM. This study recommends future study to refer to Voon, Abdullah, Lee, and Kueh (2014) TQM implementation which includes total employee involvement, continuous improvement, continuous training, teamwork, empowerment, top management commitment and support. Additionally, there is also an alternative dimension which were used by Talib et al. (2013) who have more dimensions and tailored to the banking industry. However, the consequent of using that dimensions is to involve not only the customer but also the bank's employee.

Lastly, future studies could also be improved by increasing the region scope and the bank type. If it is possible future study should also cover the entire banking industry in Indonesia. In addition, future study could also improve the Bank scope which is not only cover the SOE Banks, but also private Banks, conventional and Islamic bank.

\section{References}

Abdillah, W., \& Jogiyanto. (2015). Partial least square alternatif structural equation modeling (sem) dalam penelitian bisnis. Yogyakarta: CV Andi Offset.

Al-Tabbaa, O., Gadd, K., \& Ankrah, S. (2013). Excellence models in the non-profit context:
Strategies for continuous improvement. International Journal of Quality \& Reliability Management, 30(5), 590-612.

Baidoun, S. D., Salem, M. Z., \& Omran, O. A. (2018). Assessment of tqm implementation level in Palestinian healthcare organisations: The case of Gaza strip hospitals. The TQM Journal, 30(2), 98-115.

Calvo-Mora, A., Picón, A., Ruiz, C., \& Cauzo, L. (2014). The relationships between soft-hard TQM factors and key business results. International Journal of Operations \& Production Management, 34(1), 115-143.

Dhasan, D. K., Suwanna, \& Theingi. (2017). Building customer loyalty through service quality, customer engagement and commitment: The case of mobile network providers in Thailand. Proceeding XVI International Business \& Economy Conference (IBEC).

Fauzi, A. A., \& Suryani, T. (2019). Measuring the effects of service quality by using carter model towards customer satisfaction, trust and loyalty in Indonesian Islamic banking. Journal of Islamic Marketing, 10(1), 269-289.

Fernandes, T., \& Esteves, F. (2016). Customer engagement and loyalty: A comparative study between service context. Service Marketing Quarterly, 37(2), 125-139.

Ghozali, I., \& Latan, H. (2014). Partial least squares: Konsep, metode, dan aplikasi menggunakan program warppls 2.0. Edisi kedua. Semarang: Universitas Diponegoro.

Griffin, J. (2002). Customer loyalty how to earn it, how keep it. San Fransisco, CA: Jossey-Bass.

Hapsari, R., Clemes, M. D., \& Dean, D. (2017). The impact of service quality, customer engagement and selected marketing constructs on airlines passengers loyalty. International Journal of Quality and Service Sciences, 9 (1), 21-40.

Herzallahah, A. M., Gutiérrez-Gutiérrez, L., \& Rosas, J. F. M. (2014). Total quality management practices, competitive strategies and financial performance: The case of the Palestinian industrial smes. Total Quality Management, 25(5-6), 635649.

Khorshidi, G., Naghash, A., \& Mohammadian, M. (2014). Assessment and analysis of service quality based on hierarchical service quality model in agricultural bank. Quarterly Journal of Economic Research, 14(1), 151-168.

Kotler, P., \& Keller, K. L. (2012). Marketing management. $14^{\text {th }}$ Edition. Essex: Pearson Education Inc.

Lau, A. W. T., \& Tang, S. L. (2009). A survey on the advancement of qa (quality assurance) to tqm 
(total quality management) for construction contractors in Hong Kong. International Journal of Quality \& Reliability Management, 26(5), $410-425$.

Lin, H. H. (2012). The effect of multi-channel service quality on mobile customer loyalty in an online and mobile retail context. The Service Industries Journal, 32(11), 1865-1882.

Malhotra, N. K. (2010). Marketing research: An applied orientation. Sixth Edition. Upper Saddle River, NJ: Pearson Education, Inc.

Mensah, O., J., Copuroglu, G., \& Fening, F. A. (2012). The status of total quality management (tqm) in Ghana. International Journal of Quality \& Reliability Management, 29(8), 851-871.

Mongid, A., \& Muazaroh, M. (2017). The Efficiency and inefficiency of the banking sectors: Evidence from selected ASEAN banking. Jurnal Ekonomi Malaysia, 51(1), 119-132.

Ooi, K. B., Lin, B., Tan. B. I., \& Chong, A. Y. L. (2011). Are TQM practices supporting customer satisfaction and service quality? Journal of Services Marketing, 25(6), 410-419.

Petnji, Y. L. H., Marimon, F., \& Casadesus, M. (2011). Customer's loyalty and perception of iso 9001 in online banking. Industrial Management \& Data Systems, 111(8), 1194-1213.

Psomas, E. L, \& Jaca, C. (2016). The impact of total quality management on service company performance: Evidence from Spain. International Journal of Quality \& Reliability Management, 33(3), 380-398.

Rad, A. M. M. (2005). A survey of total quality management in Iran. Leadership in Health Services, 18(3), 12-34.

Rahmayanti, N. (2010). Manajemen pelayanan prima. Yogyakarta: Graha Ilmu.

Ribbink, D., Van Riel, A. C., Liljander, V., \& Streukens, S. (2004). Comfort your online customer: Quality, trust and loyalty on the internet. Managing Service Quality: An International Journal, 14(6), 446-456.
Sadikoglu, E., \& Zehir, C. (2010). Investigating the effects of innovation and employee performance on the relationship between total quality management practices and firm performance: An empirical study of Turkish firms. International Journal of Production Economics, 127(1), 13-26.

Shayestehfar, R., \& Yazdani, B. (2019). Bank service quality: A comparison of service quality between BSI branches in Isfahan and Dubai. The TQM Journal, 31(1), 28-51.

So, K. K. F., King, C., Sparks, B. A., \& Wang, Y. (2016). The role of customer engagement in building brand loyalty to tourism brands. Journal of Travel Research, 2016, 55(1), 64-78.

Sugiyono. (2015). Metode penelitian kuantitatif kualitatif dan $r \& d$. Bandung: Alfabeta.

Suryani, T. (2013). Perilaku konsumen di era internet. Yogyakarta: Graha Ilmu.

Talib, F., Rahman, Z., \& Qureshi, M. N. (2013). An empirical investigation of relationship between total quality management practices and quality performance in Indian service companies. International Journal of Quality \& Reliability Management,30(3), 280-318.

Voon, B. H., Abdullah, F., Lee, N., \& Kueh, K. (2014). Developing a hospise scale for hospital service excellence. International Journal of Quality \& Reliability Management, 31(3), 261-280.

Weckenmann, A., Akkasoglu, G., \& Werner, T. (2015). Quality management-history and trends. The TQM Journal, 27(3), 281-293.

Zairi, M. (2013). The tqm legacy - Gurus' contributions and theoretical impact. The TQM Journal, 25(6), 659-676.

Zakuan, N. M., Yusof, S. M., Laosirihongthong, T., \& Shaharoun, A. M. (2010). Proposed relationship of tqm and organizational performance using structured equation modelling. Total Quality Management \& Business Excellence, 21(2), 185-203. 